\title{
PUTTING UNIFORMITY IN FINANCIAL ACCOUNTING INTO PERSPECTIVE
}

\author{
WELDON PoweLL*
}

I

\section{Historical Background}

In dealing with any of the major accounting problems it is worth while, I think, to bear in mind its historical backround. Remembering the past usually assists in understanding the present and planning the future.

Here two points are of especial interest. The first is that modern financial accounting is a relatively new development-one that has come about largely within the lifetime of a number of accountants who are in active practice today.

As recently as the 1890 s the amount provided for depreciation by a number of large corporations was considered to be a function of profits. The first modern published report of a major industrial corporation that I know of-that of United States Steel Corporation for the year 1902-was issued in 1903. Only about twentyfive years before that time a stockholder of a large railroad company who requested information concerning the company had been told that it had issued no statements for at least five years and had no intention of making its financial affairs known to the public.

The correspondence between the American Institute of Certified Public Accountants (AICPA, then the American Institute of Accountants) and the New York Stock Exchange, in which the origin of the expression "generally accepted accounting principles" is to be found, took place in the early r930s-less than thirty-five years ago. The Securities and Exchange Commission came into existence in $1934 .^{2}$ The first statement by the American Accounting Association on accounting principles was issued in $1936,{ }^{3}$ and the significant monograph by Professors Paton and Littleton, An Introduction to Corporate Accounting Standards, which supplemented it, was published in $19400^{4}$

- B.S. I922, M.S. I923, University of Illinois. Certified Public Accountant, New York, North Carolina, and several other states; with Haskins \& Sells since 1924, partner since 1934. Member of the American Institute of Certified Public Accountants; Chairman of the Special Committec on Rescarch Program, 19571958; Chairman of the Accounting Principles Board, I959-1963; Member of Council, I962-1965. VicePresident of the American Accounting Association, 1953-1954. Author of various articles in accounting and auditing periodicals.

With deep regret, the editors of Law and Contemporary Problems record the death of Mr. Powcll after his completion of this article but before its publication.

${ }^{1}$ American Instrtute of Accountants, Audits of Corporate Accounts 27 (1934) [the American Institute of Accountants is hereinafter cited as AIA].

${ }^{2}$ Securities Exchange Act of $1934, \S_{4}$ (a), 48 Stat. 885 , as amended, $x_{5}$ U.S.C. $578 d$ (a) (1964).

${ }^{3}$ American Accodnting Ass'n, A Tentative Statement of Accounting Principles Underlyino Corporate Financial Statements, reprinted in II Accounting Rev. r87 (1936).

W. A. Paton \& A. C. Littleton, An Introduction to Corporate Accounting Standards (i940). 
The first committee of the AICPA to deal comprehensively with accounting principles was formed in 1938, and all of the Institute's pronouncements have been issued since then. That year also saw the publication of $A$ Statement of Accounting Principles by Professors Sanders, Hatfield, and Moore. ${ }^{5}$ Accounting Concepts of Profit by Professor Gilman ${ }^{6}$ appeared in I939. The Study Group on Business Income, under the leadership of George O. May, published its report, Changing Concepts of Business Income, in 1952."

To those who complain about the seemingly slow rate at which the development of accounting principles is proceeding today I suggest that consideration of this chronology should demonstrate that substantial progress has indeed been made, that time is needed to reach a consensus on important matters, and that patience is requisite.

The second point of interest is that, except for the uniform classifications of accounts issued by several industry groups for the guidance of their members, and the accounting requirements promulgated by numerous federal, state, and local regulatory authorities applicable to the companies subject to them, there has been a notable absence of any attempt to impose uniform accounting principles or practices on business corporations.

In this connection it may be noted that the regulations issued under the Internal Revenue Code, taking the approach that has been followed in federal income-tax law for nearly fifty years, contain the following provision:

It is recognized that no uniform method of accounting can be prescribed for all taxpayers. Each taxpayer shall adopt such forms and systems as are, in his judgment, best suited to his needs. However, no method of accounting is acceptable unless, in the opinion of the Commissioner, it clearly reflects income. A method of accounting which reflects the consistent application of generally accepted accounting principles in a particular trade or business in accordance with accepted conditions or practices in that trade or business will ordinarily be regarded as clearly reflecting income, provided all items of gross income and expense are treated consistently from year to year. ${ }^{8}$

The proposal that grew out of the discussions between the AICPA and the New York Stock Exchange in the early I930s was that listed corporations be permitted to choose their own methods of accounting within very broad limits, but that they be required to disclose such methods and to undertake not to make material changes in them without due notice to interested persons. This, it was thought, would promote consistency, and would tend to bring about the elimination of less desirable practices by exposing them, although it was recognized that improvement

\footnotetext{
TThomas H. Sanders, Henky R. Hatfield \& Underhild Moore, a Statement of Accounting Princtples (1938).

- Stephen W. Gitafan, Accounting Concepts of Profit (I939).

${ }^{7}$ Study Group on Business Income, Changing Concepts of Business Income (I952).

${ }^{8}$ Treas. Reg. $\$$ I.446-r(a)(2) (1954).
} 
would be gradual. Independent auditors were to be expected to express an opinion on whether the financial statements conformed with the methods purported to be followed and on whether those methods were in harmony with good accounting standards, that is, with "accepted accounting principles." (The word "generally" was added later.) Although there was concern then, as there is now, because of the variety of accounting practices in use, the correspondence between the Institute and the Exchange stated that the arguments against "the selection by competent authority out of the body of acceptable methods in vogue ... of detailed sets of rules which would become binding on all corporations of a given class," were "overwhelming."

The activities of the Institute in the area of financial accounting since then have been oriented toward defining sound practice and narrowing the areas of difference and inconsistency in existing practice.

When the Committee on Accounting Procedure was organized a few years later it announced in the beginning that its plan would be "to consider specific topics, first of all in relation to the existing state of practice, and to recommend, wherever possible, one or more alternative procedures as being definitely superior in its opinion to other procedures which have received a certain measure of recognition and, at the same time, to express itself adversely in regard to procedures which should in its opinion be regarded as unacceptable." It also said that in dealing with each case, especially where alternative methods seemed to possess substantial merit, it would aim to take into account the conflict of considerations that made such a situation possible and thus gradually to prepare the way for a further narrowing of choices. ${ }^{10}$ The Committee inaugurated a series of accounting research bulletins, of which fifty-one were issued during the next twenty-two years. These relate to particular issues, and do not present a comprehensive outline of accounting principles or practices. Their authority was stated to rest upon the general acceptability of the opinions expressed in them. With minor exceptions, however, they have been recognized as authoritative on the subjects dealt with, and several of them have led to changes in practice. Altogether they have had a significant effect.

The charter of the present Accounting Principles Board, which came into existence in 1959, states the Institute's purpose in the field of financial accounting to be generally as follows:

The general purpose of the Institute in the field of financial accounting should be to advance the written expression of what constitutes generally accepted accounting principles, for the guidance of its members and of others. This means something more than a survey of existing practice. It means continuing effort to determine appropriate practice and to narrow the areas of difference and inconsistency in practice. 11

\footnotetext{
'AIA, Audits of Corporate Accounts 8-9 (1934).

${ }^{20}$ Committee on Accounting Procedure, AIA, 1939 Midyear Report, in AIA, 1939 Yearboor 139.

${ }^{11}$ Special Comas. on Research Program, Aicpa, Report to Council (1958), reprinted in J.
} 
The authority of opinions of the Board is stated to rest upon their general acceptability, as did the accounting research bulletins of the predecessor Committee.

The Securities Act of $1933,{ }^{12}$ although it gives the Securities and Exchange Commission broad powers in connection with accounting methods and practices, has always been regarded as a disclosure law, and the Commission has not fully exercised its powers in this connection. The approach taken by the Commission is indicated in a memorandum prepared by the office of the Chief Accountant in 1964 in response to a request of the Subcommittee on Commerce and Finance of the House of Representatives Committee on Interstate and Foreign Commerce during the course of hearings on two bills relating to the protection of investors. ${ }^{13}$ The Chairman of the Subcommittee had asked the Chairman of the Securities and Exchange Commission for a statement setting forth the areas where alternative practices could produce materially different results under generally accepted accounting principles and the reasons why the Commission considered that investors were adequately protected by its acceptance of the alternative practices. The memorandum contains an excellent summary of the background of the Commission's approach to accounting and reporting, and concludes with this paragraph:

As stated previously, and alluded to in this release, the Commission has cooperated throughout the years of its existence with representatives of the American Institute of Certified Public Accountants, and others, in an endeavor to develop and promote better financial reporting, and a more general acceptance of sound accounting practices. Experience has borne out that the investor, and the public, are best served by this practice, and by the policy of requiring a certificate of independent accountants which expresses an opinion as to the overall fairness of the financial position and operating results reported upon, and the avoidance of prescribing detailed regulations as to accounting methods, practices, or principles. No legislative endorsement of this policy is considered necessary. ${ }^{14}$

In mentioning these developments, of course, I do not intend to imply that financial accounting necessarily must follow the same course in the future that it has followed in the past. I wish simply to suggest that the existing arrangements reflect the thinking of some eminent accountants who have devoted considerable time and attention to them over the years, and we should be sure of our ground before we move away from them.

\section{II}

\section{CONCEPTS OF UNIFORMITY}

There is much loose talk about uniformity in accounting. Accordingly, it may be worth while at this point to give a little thought to just what is meant by it.

Accountancy, Dec. 1958, pp. 62-63. See also New Institute Research Program, J. Accountancy, June I959, p. 7.

${ }_{19}^{19} 8$ Stat. 74 , as amended, I5 U.S.C. $\$ \$ 77 \mathrm{a}$-aa $(1964)$.

${ }^{13}$ Hearings on H.R. 6789, H.R. 6793, and S. 162 Before the Subcommittee on Commerce and Finance of the House Committee on Interstate and Foreign Commerce, 88th Cong., 2d Sess., pt. I, at 1299 (I964).

14 Id. at 1305 . 
Dictionary definitions cannot always be applied in technical areas. However, two definitions of "uniform" seem to be pertinent to this discussion: "conforming to one rule or mode" and "not varying or variable."1s These ideas seem to be those in the minds of most persons concerned with uniformity. However, there seem to be divergent views about how strict the rule should be and how variable practice should be.

One view supports absolute uniformity. It may be illustrated by the following statement, which appeared in a brochure issued by a New York securities dealer a few years ago:

Uniform accounting practice is the answer to a security analyst's prayer. What a joy to produce long spread sheets where each vertical column represents a different company and to compare each item of the balance sheet and earnings statement by merely running one's finger across the line. To be able to come to the definite conclusion that the stock of this particular company represents truly the best value.10

Another view would take into account the effect of circumstances. Those who hold this view say that uniformity in accounting means identical treatment except where circumstances differ. Thus the Special Committee on Opinions of the Accounting Principles Board, in reporting to the Council of the AICPA in the spring of 1965, made as the second of its recommendations the following:

The Board should move toward the reduction of alternative practices in accounting by adopting policies under which it will:

a. Recognize the objective that variations in treatment of accounting items generally should be confined to those justified by substantial differences in factual circumstances.

b. Set forth in its Opinions the criteria for application of such acceptable variations.

c. In an Opinion dealing with a situation which the Board believes justifics alternatives even though there is no significant difference in factual circumstances, set forth the treatment to be preferred, and require disclosure of the treatment followed. ${ }^{17}$

A similar approach is the one holding that all accounting should be subject to the same broad principles but that latitude should be allowed in the methods of applying these broad principles in practice. Selection of the methods to be used in individual situations would be left to the judgment of management, subject to review by auditors.

Some persons equate uniformity with comparability. They consider that there should be that degree of uniformity in accounting that is capable of producing

\footnotetext{
${ }^{20}$ WeEsTER'S NEW INTERNATIONAX DiCtionaRY (2d ed. unabridged, 1959).

${ }^{10}$ Kuget, Stone \& Co., 1960 BanK Stock Guide (New York ed.).

${ }^{17}$ Spectal Comas. on Opinions of the Accounting Principles Board, Aicpa, Report to Council 7 (1965).
} 
financial statements that are comparable, certainly among companies in the same industry and perhaps among companies in different industries.

Let us examine these various concepts.

\section{A. Absolute Uniformity}

In my view, absolute uniformity in financial accounting may be the stuff a security analyst's dreams are made on, but it is not a practicable approach to the study of a set of financial statements. I doubt that very many persons take it seriously.

If an attempt were to be made to institute uniform accounting in business corporations generally, it first would be necessary to develop a system of accounts and reports. This would mean a chart of accounts, with comprehensive instructions concerning the entries to be made in each of them. Such instructions would have to prescribe costing methods, property accounting procedures, including depreciation practices and rates, principles for allocating expenditures for research and development and similar items among periods of time, forms of reporting, and innumerable other details. The difficulties that would be involved in developing such a system of accounts and reports for any one industry would be formidable. Those that would be encountered in developing a system for business corporations generally-extractive, manufacturing, retail, finance, and all the others-would be well nigh insuperable.

Even if a workable system of accounts and reports could be developed for use in business corporations generally, it would require government fiat to put it into effect and government regulation to maintain it. Surely few if any would regard the prospect of this with equanimity.

The uniform systems that have been developed for certain industries have taken a somewhat broad approach to some matters, and the companies that have used them have had to alter them or supplement them to meet their peculiar situations. The experience of regulated industry-railroads, public utilities, insurance companies, and the like-which sometimes is cited in support of a uniform approach to financial accounting, is illuminating. These companies have a great measure of uniformity in the conditions under which they operate, the products or services they sell, the customers they serve, and the means they employ in distributing their output. The companies are subject to the jurisdiction of governmental regulatory commissions with full-time commissioners and staff. Accounting performs for them the special function of providing a basis for rate-making, a function that in industry is left to the forces of supply and demand. In these circumstances uniform accounting would be expected to be at its most effective. But even here it is not fully achieved; there is perhaps greater diversity in the accounting among regulated companies than is generally recognized. One indication of this is the divergence in the views held by federal, state, and local commissions on the proper accounting for the investment credit. 
It is because of considerations such as these that diversity in accounting among independent entities is listed as one of the basic concepts to which accepted accounting principles are oriented, in Paul Grady's recent Inventory of Generally Accepted Accounting Principles for Business Enterprises. The author comments as follows:

Recognition of the concept of diversity in accounting among independent entities, as a fact of business life, in no way imperils the objective of the Accounting Principles Board to "narrow the areas of difference in accounting" and to promote continuous improvement and greater comparability in financial statements. It does, however, place the objective within realistic limits which fall considerably short of uniformity. ${ }^{18}$

I fully support this position.

\section{B. Effect of Circumstances}

The notion that uniformity in accounting means identical treatment except where circumstances differ obviously has plausibility. However, one of the members of the Special Committee on Opinions of the Accounting Principles Board recognized that it would present problems in practice. His comments on it were set forth in the report of the Special Committee as follows:

Paul Grady believes that Recommendation 2 greatly oversimplifies the matter of alternative accounting practices and overstates the extent of change which the Board should be expected to bring about. Until it has been demonstrated that distinguishing criteria can be established for such common alternative methods as are now in use for the pricing of inventories and allocation of depreciation charges to fiscal periods, he believes it is unrealistic to hold out an objective that alternatives should be restricted to differences in circumstances. ${ }^{10}$

I think this is a sound criticism and a reasonable appraisal of this approach to uniformity.

Circumstances, of course, do vary. Among the obvious things that may have an effect on the accounting of a business enterprise are the nature of the industry of which it is a part, the type of product it sells or services it renders, the terms upon which it bills its customers or clients, the areas of the world in which it operates, the extent to which it engages in research and development activities, the legal requirements (including the provisions of the income-tax laws) to which it is subject, its organizational structure, and the attitude of its management. The impact of most of these things on the accounting in various situations should be readily apparent.

Consider for example the last item listed, which is one of the most importantthe attitude of management. The more $I$ see of business enterprises, the more convinced I am of the importance of management attitude. One needs only to look

\footnotetext{
${ }^{18}$ Paul Grady, Inventory of Generally Accepted Accounting Principles for Business EnterPRISES 35 (AICPA Accounting Research Study No. 7, x965).

${ }^{19}$ Special Comm. on Opinions of the Accounting Principles Bonrd, AicPa, Report to Council $7(1965)$.
} 
around him, to observe the rise and fall of business organizations, to see that this is so. To a large extent the attitude of management shapes the course of the business. Where there is uncertainty concerning future events, management's appraisal of the situation determines the accounting and reporting. One management may be imaginative, another dull; one bold, another cautious; one conservative, another optimistic; one forward-looking, another antiquated; one alert to the effective use of accounting data, another not; and so on. Two managements approaching the same problem with divergent outlooks may arrive at materially different conclusions on it-a circumstance that may affect importantly both the course of the business and the accounting for it.

The effect of management attitude may be illustrated by a simple example. The management of one company may consider that it can create a demand for large quantities of a product during the near future and may acquire a plant to manufacture the product with the intention of doing this, despite some uncertainty concerning the use to which the plant may be put after the initial demand for the product is met. The management of a second company, on the other hand, may believe that it can market a product more or less constantly over a relatively long period of time, and may acquire a manufacturing plant with the expectation of using it for many years. The two plants may be similar in all respects-location, size, construction, layout, equipment, and cost. But the management of the first company will provide for depreciation of its plant by means of an accelerated method, thus absorbing the major part of the cost of the plant in operations over a relatively short period, whereas the management of the second company will depreciate its plant through a straightline method, thus writing off the cost of the plant ratably over a relatively long period. If both companies operate in an industry in which a large investment in plant is necessary, their operating results may be significantly affected by accounting for depreciation.

But a great many times in practice the effect of management attitude, and of other circumstances as well, is not so easily identifiable and measurable as in the simple example given. Thus, while it is clear that circumstances do vary and that different circumstances call for different accounting treatments, it is not clear how one distinguishes among circumstances and chooses among accounting treatments. What is a circumstance in which a departure from customary practice is permissible? How much of a departure is tolerable? If the circumstance is a legal requirement, such as a provision of the income-tax law or a requirement of governmental regulatory authority, what is the best way to deal with it? Until these questions and others like them can be answered satisfactorily, it seems imprudent to hold out the hope that variations in accounting treatment can be geared exclusively or largely to differences in circumstances. It may be that in the course of time a consensus will be reached on these matters, but it is doubtful that this will come about in the near future. 


\section{Broad Principles}

We come now to the approach to uniformity that holds that the broad principles underlying all accounting should be the same but that the methods of applying these broad principles should be permitted to vary.

There cannot be any doubt about the desirability of arriving at a consensus on the fundamentals of accounting in those areas where substantial agreement has not already been achieved. Further, there should not be much doubt about the feasibility of doing this if a determined effort is made to do it. However, while it is likely that a consensus would tend to eliminate some of the divergencies that exist on specific issues, it could not be expected to result in uniformity in accounting for several reasons.

The methods of applying broad principles in practice differ significantly. A list of the major alternative methods in use today is given in Paul Grady's Inventory. ${ }^{20}$ In commenting on it the author says that it "is evident that variety of applications causes the major share of the differences in accounting among entities, rather than differences among the broader accounting principles listed in the summary of this Inventory."21 Until the field of alternative practices can be narrowed, there will continue to be diversity in financial statements, whether or not there is agreement on the broad principles of accounting.

Further, the accounting process includes the use of estimates and the exercise of judgment to a significant extent. In fact these are among the most important features of accounting. Estimates are made and judgments are exercised by men, and therefore diversity in the accounting results is bound to exist. This is true especially as regards the assignment of revenues, costs, expenses, and losses to accounting periods, and thus the determination of periodical earnings. On this point Accounting Research Bulletin No. 43 contains the following passage:

Profits are not fundamentally the result of operations during any short period of time. Allocations to fiscal periods of both charges and credits affecting the determination of net income are, in part, estimated and conventional and based on assumptions as to future events which may be invalidated by experience. While the items of which this is true are usually few in relation to the total number of transactions, they sometimes are large in relation to the other amounts in the income statement. ${ }^{22}$

That the swing between the conclusions of two managements approaching the same facts from different viewpoints can sometimes be a wide one has been evident in several situations that have been reported in the financial press during the past few years.

\footnotetext{
${ }^{20}$ The list is set forth in Appendix $D$ at the end of this symposium.

${ }^{21} \mathrm{GraDY}$, op. cit. supra note 18 , at 380 . The summary referred to is set forth in Appendix $C$ at the end of this symposium.

29 Committee on Accounting Procedure, AICPA, Restatement and Revision of Accountino Research Bulletins 59 (AICPA Accounting Research Bull. No. 43, I953).
} 
At this point there should be mentioned the effect of the income-tax laws. Financial income and taxable income are not necessarily the same. In fact they frequently differ significantly. The tax laws provide for exemptions and special treatments and contain other provisions reflecting congressional decisions of policy influenced by social, economic, or political factors. The income-tax laws, however, sometimes influence financial accounting. For example, the use of the last-in-first-out method of costing sales and inventories for income-tax purposes is dependent upon its being used also in the books of account. Again, the acceptance by the Internal Revenue Service of certain depreciation practices and rates sometimes is cited by business corporations as support for using the same practices and rates for financial accounting purposes. There is no indication that the existing gap between the provisions of the income-tax laws and the requirements of generally accepted accounting principles in certain areas is likely to be closed in the near future.

I conclude that while agreement on broad principles would be helpful, it would not bring about uniformity.

\section{Comparability}

There are two aspects to comparability. One relates to consideration of the financial statements of an individual concern from period to period. The other relates to consideration of the financial statements of one concern in relation to those of another concern.

Comparability of the published financial statements of a given business from period to period has been effectively achieved in practice during the past thirty years through the adoption of the two concepts of consistency and disclosure in financial reporting. The auditing standards of the AICPA require among other things that the auditors, in their report on the financial statements of a concern, $(a)$ state whether the statements are presented in accordance with generally accepted principles of accounting, $(b)$ state whether such principles have been consistently observed in the current period in relation to the preceding period, and (c) make any informative disclosures they regard as necessary that are not made in the statements themselves. When there is a change in the accounting principles, the change must be disclosed and its effect must be stated. ${ }^{23}$ The rules of the Securities and Exchange Commission contain similar requirements. The Commission's rule on this point is specific, and refers to "any change in accounting principle or practice, or in the method of applying any accounting principle or practice, made during any period for which financial statements are filed which affects comparability of such financial statements with those of prior or future periods."24

Some persons regard consistent application of sound accounting principles from

\footnotetext{
${ }^{23}$ Conmattree on Auditing Procedure, AiCPA, Audittng Standards and Procedures i6, 42 (Statement on Auditing Procedure No. 33, 1963).

${ }^{24}$ SEC Reg. S-X, Rule 3-07, 17 C.F.R. § 210.3-07 (1964).
} 
period to period within each individual enterprise, accompanied by adequate disclosures concerning its affairs, as of greater significance than comparability among enterprises. At all events, it is important not only in making investment decisions but also in appraising the performance of management over a period of years. I am old-fashioned enough to believe that one of the important functions of financial statements is to portray the accounting of management for its fiduciary responsibilities.

On the other hand, many persons seem to take the position that the financial statements of a public company should be prepared mainly for use by investors in deciding whether to buy, sell, or hold stocks, and that investment decisions would be made much easier if the statements of all corporations reflected the same accounting procedures. They have a point, of course. I concede that comparability is a desirable thing. I agree also that there are several areas in accounting where it does not exist to the extent that it should and that something should be done about these. At the same time I think that there is a limit to the degree of comparability that ever can be expected to exist in the published financial statements of businesses generally in our free-enterprise system. Incidentally, there is a limit also to the extent to which the historical financial statements of a company can be used to project future earnings.

At the outset it should be recognized that the areas in which the greatest diversity exists in the accounting and reporting are those in which the knottiest problems lie. Even a casual reading of that part of Paul Grady's Inventory relating to alternative methods ${ }^{25}$ will serve to demonstrate this. Among the important subjects for which alternatives exist are the accounting for research and development, pensions, income taxes, investments in other companies, and intangible assets, and the reporting of income. All of these, incidentally, are now under consideration as a part of the accounting research program of the AICPA. Perhaps inventory valuation methods and depreciation and depletion methods should be added to the list. Satisfactory solutions to these difficult problems have not yet been found. Solutions to some of them may result from the current activities of the Institute, but I suspect that progress on most of them is likely to take the form of the gradual narrowing of differences in practice.

Some users of financial statements seem inclined to criticize the accountants for almost all lack of comparability, no matter what its cause. Of course one of the principal reasons that the statements of one company may differ from those of another is that the two companies follow different business practices in some areas. Two areas in which questions sometimes are raised in this regard are incentive compensation and property. One company may pay cash bonuses to its management, whereas another company may grant stock options to its management. One may

\footnotetext{
${ }^{28}$ GRADY, op. cit. supra note 18 , at $373-79$ (set forth in Appendix D at the end of the symposium).
} 
own the property in which it carries on its business, whereas another may lease a substantial part of the property it occupies. Some persons seem to think that in cases such as these, accounting adjustments of some kind should be made, to bring about uniformity in the reporting. In fact such adjustments sometimes are made, but they customarily are restricted to situations in which the form of a transaction clearly does not reflect its substance and in which it seems desirable that the accounting should follow the substance. As an example there may be cited certain leases, concerning which the Accounting Principles Board has issued an opinion setting forth criteria for determining when a lease should be dealt with as a purchase by the lessee. ${ }^{26}$ These circumstances are, and in my view should continue to be, the exception. I do not believe in as-if accounting as a general rule. It usually causes confusion and sometimes has legal implications.

It is likely that the effect of business practices on the comparability of financial statements will be even greater in the future than it has been in the past. Our economy is dynamic and changing. New ways of conducting business call for novel accounting treatments. These in turn influence the form and content of financial statements. During the last decade or two we have seen the rise or substantial spread of such developments as leasing companies, condominiums, poolings, fifty per cent owned companies, small business investment companies, profit-sharing and deferred compensation plans, and pension trusts, and we have experienced a vast growth in international operations. When different companies adopt or experiment with new developments in different ways, the comparability of their financial statements is bound to be affected. The users of financial statements will have to be prepared to evaluate differences in business practices in comparing the reports of different businesses. They should, obviously, be given the facts necessary for doing so.

It needs to be emphasized that the making of an intelligent investment decision requires more than a superficial review of the most recent figures, with special attention to the reported earnings per share for the latest fiscal period. This would be so even if there were absolute uniformity in financial accounting. The fact that two amounts are the same or can be reconciled with each other is not conclusive. One needs to find out what is behind them before accepting them. Numerous factors are pertinent to investment decisions-the nature and prospects of the enterprise and of the industry of which it is a part, the condition and adequacy of its plant, the quality of its management, the form of its capital structure, and so on. The facts usually are available. They can be found in financial statements and related notes, the text of published annual reports, registration statements and periodical reports filed with the Securities and Exchange Commission, and news accounts in the financial press. Many of them affect the earnings per share but gradually over a period of time. Greater comparability in accounting and reporting practices

\footnotetext{
${ }^{26}$ Accounting Principles Board, AlCPa, Reporting of Leases in Financial Statements of Lessee (Opinion No. 5, 1964).
} 
might make it easier to deal with these facts, but it would not eliminate the necessity for considering them.

Paul Grady in his recent Inventory makes a number of penetrating comments on comparability. ${ }^{27}$ Referring to "either-or" alternative practices, he points out that so long as the significant practices are "adequately disclosed and consistently followed, the effect of differing methods on periodic income would soon be unimportant, although there might be considerable difference in balance-sheet items carried forward to future periods." He stresses that consistency in the application of accounting practices "permits comparability of financial statements from year to year for the same entity" and, as to different entities, that "investors now have the "qualitative standard of comparability' that the management and directors of each enterprise adopt and apply the accounting principles and methods, which, in their judgment, will fairly present the financial position and results of operations of that enterprise." Grady adds that investors have "the assurance inherent in the independent opinion of the certified public accountant that the statements are fairly presented in accordance with generally accepted accounting principles, which have substantial authoritative support and have been consistently applied, unless there are specific and clearly stated qualifications." Grady observes that adequate disclosure provides "a broad basis of comparison and differentiation of income statements." He suggests that business executives and financial analysts realize that "the Institute's program of gradually eliminating unjustified 'areas of difference' and of continuing to lead in the evolutionary process of improvement in accounting and reporting is the sound course to follow, even though it falls short of satisfying the type of person who yearns for simple and certain answers which are usually inapplicable to the complex problems of business." Finally, Grady emphasizes that "the greatest single step toward providing . . . a relatively high degree of comparability" would be a system of reflecting price-level changes in financial statements, and suggests presentation of supplmental statements adjusted to take account of such changes.

In view of the significant changes that have occurred, and that continue to occur, in the value of the dollar, I would agree on the desirability of furnishing the supplemental statements mentioned. Generally, however, I do not favor presentations showing what the results would have been if an accounting treatment other than the one actually used had been adopted. On the whole I think such presentations tend to confuse rather than help the readers of financial statements. Security analysts frequently find it desirable to make computations giving effect to alternative treatments during the course of their work, but they usually are able to obtain without great difficulty the information they need for their purposes, and their expertise in their field assures that they will be able to use it intelligently.

The foregoing discussion of comparability has concerned itself with accounting

\footnotetext{
${ }^{27}$ GRADY, op. cit. supra note $I 8$, at $380-82$. The material summarized in this paragraph is quoted in full in Flynn, Uniformity in Financial Accounting: A Progress Report, supra, pp. 623-36, at 63x-32.
} 
procedures in the United States. The accounting procedures in foreign countries frequently differ from those in this country, and the differences sometimes are significant. The accounting practices in many foreign countries are influenced by legal considerations, especially in the income-tax area, which materially affect inventories, depreciation, and other important items in the financial statements. Incomeequalizing devices such as secret reserves sometimes are employed. The reporting practices in many foreign countries do not require the disclosure of certain information, such as volume of sales, that is commonly given here. Accordingly, the reports of foreign companies frequently lack comparability with those of United States companies in material respects. It is likely that improvement in the situation will be slow. However, the Committee on International Relations of the AICPA is aware of the problem and is interested in it. The Committee recently undertook a survey of foreign accounting procedures, and has just published Professional Accounting in 25 Countries, ${ }^{28}$ which presents the results of this work.

\section{Conclusion}

In considering what should be done, the first point to be borne in mind is that the financial statements of a business enterprise are primarily the responsibility of its management and that the management is expected to adopt those accounting and reporting procedures that in its judgment will best portray the financial position and operating results of the enterprise. The auditors' function, as has been indicated, is to consider the soundness and acceptability of the procedures adopted by the management, ascertain whether they have been consistently applied, and see that all necessary informative disclosures are made.

Nevertheless, the accountancy profession, I believe, should take the lead in the advancement of financial accounting. The AICPA is in a position to do this, and its influence in developing principles and practices and securing their adoption could be very great. The Institute is composed of individuals many of whom have expertise in the field of financial accounting. It has ready access to all segments of the business community. It is able to assume the financial burden of a substantial program. In the Accounting Principles Board and the Accounting Research Division of the Institute it has a vehicle for organizing and carrying out an effective program. However, the Institute should find some means of working much more than it has done in the past with industry, with teachers, with other professions, with trade associations, and with government. The support of industry is especially important. The development of accounting principles and practices should be a truly cooperative effort.

Those interested in the details of the organization and operation of the Institute's accounting research program and related activities may refer to the report of the

\footnotetext{
${ }^{28}$ Committee on International Relations, AicPa, Professional Accounting in 25 Countries $(1964)$.
} 
Special Committee on Research Program, issued in $1958,{ }^{29}$ and the two reports of the Special Committee on Opinions of the Accounting Principles Board, issued in $\mathrm{x} 964$ and $1965^{30}$

The program the Institute is following places emphasis on research, and rightly so. Both theoretical and practical research are necessary to progress. We should study the theoretical aspects of every issue. A firm foundation in theory is requisite to the development of a sound superstructure of accounting practices and procedures. At the same time we should explore the practical aspects-consider the attitudes of management that cause economic facts to be what they are, the reasons underlying existing practices, the practical problems that would be involved in making changes, and the effect that changes in existing arrangements would be likely to have on those concerned by them. An important criterion of the success of research in accounting is the usefulness of its results. And by usefulness I mean not so much the possibility that something may be used but rather the likelihood that it will be used. Accounting is nothing if not essentially utilitarian in nature. Accounting procedures, if they are to be generally acceptable, must be practically applicable.

As I have already indicated, we need to reach a consensus, in the areas in which agreement does not now exist, on the fundamentals of accounting-guidelines that will establish the framework for and the boundaries to acceptable practice-whether they are called principles, postulates, concepts, or something else. The guidelines should be interrelated, integrated, and internally consistent, and new problems should be considered in relation to them and in relation to each other instead of as isolated matters to be dealt with pragmatically. Such guidelines should be directly related to and completely compatible with the social, economic, and legal conditions surrounding modern business. In other words, they should be sound practically as well as theoretically. Paul Grady's Inventory is an excellent summary of the thinking in this area as it has developed up to this time, and it should furnish an ideal starting point for further work.

At the same time we should undertake studies of specific matters. On unsettled and controversial issues, however, it is necessary to proceed with caution. The aim should be to narrow the areas of difference and inconsistency in practice, with a view perhaps of disposing of them eventually, but not to eliminate them forthwith. The complex issues in accounting cannot be disposed of as neatly as Alexander solved the problem of the Gordian Knot. We should begin to work around the edges of some of these issues, to whittle away at some of the manifestly undesirable aspects of present-day financial accounting practice, to establish preferences in various areas and work toward them, to agree upon a range of acceptability in some areas. One of the difficulties is that the art of accounting rests only in part on demonstrable

\footnotetext{
${ }^{99}$ Special Comar. on Resenrch Program, op. cit. supto note ix.

${ }^{30}$ Special Comm. on Opinions of the Accounting Principles Board, AiCPA, Report to Council (1964) and Report to Council (1965).
} 
truths. It relies heavily on conventions--propositions that are acceptable but cannot be proved to the exclusion of all others. This is one reason why the evolution of accounting procedures cannot be forced. The process is to reach an agreement on conventions that cannot be proven categorically. When something like a consensus is in sight, the Accounting Principles Board can take a firm position, not before.

We need also to mount an all-out educational campaign to get people to understand the facts of life about financial accounting. Ignorance about the financial statements and affairs of business is widespread. Many business men do not grasp the significance of accounting data or appreciate their usefulness to them. Many investors, both large and small, do not read the reports furnished to them, or do not understand the reports. Some security analysts seem to be interested more in the quantity than the quality of available information and are not prepared to deal with unusual items that cannot be neatly compartmentalized or reduced to cents per share. Some financial writers do not have enough knowledge of accounting. Entirely too much emphasis is placed on earnings per share, and much too little attention is given to the items that enter into the determination of net income.

The suggestion has been made that the way to deal with this situation is to produce financial reports that are simple. I am afraid this is impossible. There are, of course, presentations that are unnecessarily involved, explanations that are obscure, language that is unduly technical, and print that is altogether too fine. But business is complex, and there is a point beyond which it is not possible to simplify the financial statements that pertain to it. The following excerpt from a statement issued several years ago by the American Accounting Association is a good one:

The underlying determinant of adequacy of disclosure in published financial reports is their usefulness in making decisions, particularly with respect to investment problems. It is reasonable to assume that any recipient desirous of making effective use of a financial statement must be willing and competent to read it carefully and with discrimination. Such statements should, therefore, be prepared for use by interested persons having a working knowledge of business methods and terminology. 31

The problem, I suggest, is to see that these persons acquire this knowledge.

\footnotetext{
${ }^{31}$ Committee on Concepts and Standards, American Accounting Ass'n, Accounting Concepts and Standards for Corporate Financial. Statements and Preceding Statements and Supplements 46 (1957 rev.).
} 